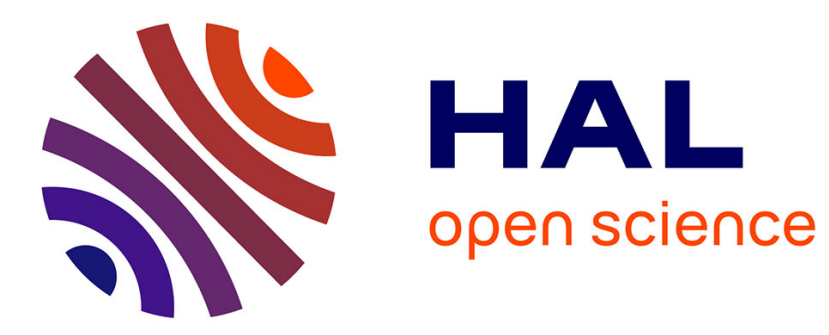

\title{
EXAFS Study of Thermal Treatment of Pb-Zr Alkoxide Precursors
}

\author{
I. Arcon, B. Malic, A. Kodre, M. Kosec, R. Frahm
}

\section{To cite this version:}

I. Arcon, B. Malic, A. Kodre, M. Kosec, R. Frahm. EXAFS Study of Thermal Treatment of PbZr Alkoxide Precursors. Journal de Physique IV Proceedings, 1997, 7 (C2), pp.C2-1193-C2-1194. 10.1051/jp4:19972189 . jpa-00255258

\section{HAL Id: jpa-00255258 https://hal.science/jpa-00255258}

Submitted on 1 Jan 1997

HAL is a multi-disciplinary open access archive for the deposit and dissemination of scientific research documents, whether they are published or not. The documents may come from teaching and research institutions in France or abroad, or from public or private research centers.
L'archive ouverte pluridisciplinaire HAL, est destinée au dépôt et à la diffusion de documents scientifiques de niveau recherche, publiés ou non, émanant des établissements d'enseignement et de recherche français ou étrangers, des laboratoires publics ou privés. 


\title{
EXAFS Study of Thermal Treatment of Pb-Zr Alkoxide Precursors
}

\author{
I. Arcon, B. Malic, A. Kodre, M. Kosec and R. Frahm*
}

Jozef Stefan Institute, Jamova 39, P.P. 3000, 1001 Ljubljana, Slovenia

and Department of Physics, University of Ljubljana, Slovenia

* Hamburger Synchrotronstrahlungslabor, DESY, Notkestrasse 85, 22603 Hamburg, Germany

\begin{abstract}
The local environment of $\mathrm{Zr}$ atoms in amorphous precursors and intermediate products of the thermal treatment leading to perovskite $\mathrm{PbZrO} 3$ ceramic materials is studied by EXAFS. The coordination of $\mathrm{Zr}$ depends significantly on the choice of the starting $\mathrm{Zr}$ alkoxide. The $\mathrm{Zr}-\mathrm{O}-\mathrm{Zr}$ bond in an amorphous phase persists till the final stage of heating at $800^{\circ} \mathrm{C}$.
\end{abstract}

The notable ferroelectric properties of $\mathrm{Pb}(\mathrm{Zr}, \mathrm{Ti}) \mathrm{O}_{3}$ based ceramics (PZT) in thin film as well as in bulk form are exploited in numerous technological applications. Within research studies on PZT based materials [1] the alkoxide based sol-gel technique has been used to prepare lead zirconate as a model substance for $\mathrm{Zr}$-rich solid solutions. The advantage of the technique as compared to solid state synthesis lies in improved homogeneity of ceramic materials and lower processing temperatures [2].

The amorphous precursors of $\mathrm{PbZrO}_{3}$ based ceramic powders are prepared by dissolving anhydrous lead acetate and zirconium alkoxide (n-propoxide or n-butoxide) in the parent alcohol. The clear yellow solutions $(0.2 \mathrm{M})$ are refluxed, and byproducts are removed by distillation. The solutions are hydrolysed at room temperature with 10 moles of water per mole of lead acetate. The resultant suspensions are dried at $150^{\circ} \mathrm{C}$. The final product, a perovskite phase $\mathrm{PbZrO}_{3}$ is obtained by heating to $800^{\circ} \mathrm{C}$. Powdered samples of both precursors after drying and after heating to $400^{\circ} \mathrm{C}, 550^{\circ} \mathrm{C}$ and $800^{\circ} \mathrm{C}$ for 30 minutes in oxygen, are analysed by XRD and EXAFS.

In spite of similarity of both $\mathrm{Zr}$ sources, different reaction paths are observed in XRD of the intermediate phases: in butoxide precursor, the final perovskite phase is reached at $700^{\circ} \mathrm{C}$ through a transitory pyrochlore phase formed at $550{ }^{\circ} \mathrm{C}$. In propoxide precursor, on the other hand, metallic lead separates at $400^{\circ} \mathrm{C}$, to be reoxidized to $\mathrm{PbO}$ which is present alongside the pyrochlore phase till transition to the pure perovskite phase at $800^{\circ} \mathrm{C}$. Thus, the advantage of the molecular homogeneity in the precursor is apparently lost by $\mathrm{Pb}$ separation. The choice of the $\mathrm{Zr}$ source seems crucial for preserving the homogeneity of $\mathrm{PbZrO}_{3}$ upon thermal treatment [3]. On the other side, no information can be gained from XRD on the zirconium dynamics, due to the low long-range order in the amorphous precursor and the pyrochlore phase. Therefore, the local structure around $\mathrm{Zr}$ atoms in the precursors is studied by the EXAFS analysis.

Zirconium $\mathrm{K}$ edge EXAFS spectra were measured at HASYLAB ROEMO beamline. The unfocused radiation from the storage ring is monochromatized by double crystal $\mathrm{Si}(311)$ monochromator with a resolution below $3 \mathrm{eV}$ at $18 \mathrm{keV}$. Powdered samples were deposited on multiple layers of adhesive tape. Reference spectra were taken on empty tapes.

Table 1:. Parameters of the nearest coordination shells around $\mathrm{Zr}$ atom in $\mathrm{PbZrO}_{3}$ propoxide and butoxide precursors after drying at $150{ }^{\circ} \mathrm{C}$ and after heating to $400^{\circ} \mathrm{C}$ and $550^{\circ} \mathrm{C}$ : neighbour species, average number, distance, and Debye-Waller factor. Uncertainty of the last digit is given in parentheses.

\begin{tabular}{|c|c|c|c|c|c|c|c|}
\hline & & \multicolumn{3}{|c|}{ Propoxide } & \multicolumn{3}{|c|}{ Butoxide } \\
\hline $\begin{array}{c}\text { Sample } \\
\text { temp. }\left[{ }^{\circ} \mathrm{C}\right]\end{array}$ & $\begin{array}{c}\mathrm{Zr} \\
\text { neighbour }\end{array}$ & $\bar{N}$ & $\begin{array}{c}\mathrm{R} \\
(\AA)\end{array}$ & $\begin{array}{c}\sigma^{2} \\
\left(\AA^{2}\right)\end{array}$ & $\mathbf{N}$ & $\begin{array}{c}\mathrm{R} \\
(\AA)\end{array}$ & $\begin{array}{c}\sigma^{2} \\
\left(\AA^{2}\right)\end{array}$ \\
\hline \multirow{3}{*}{$\begin{array}{c}150 \\
\text { (dried) }\end{array}$} & $\mathrm{O}$ & $5(1)$ & $2.10(2)$ & $0.005(2)$ & $4.1(6)$ & $2.16(1)$ & $0.005(2)$ \\
\hline & $\mathrm{O}$ & $1.0(5)$ & $2.71(2)$ & $0.002(1)$ & 1 & 1 & 1 \\
\hline & $\mathrm{Zr}$ & $10(4)$ & $3.35(2)$ & $0.019(4)$ & $3(1)$ & $3.44(2)$ & $0.008(4)$ \\
\hline \multirow[t]{2}{*}{400} & 0 & $6(1)$ & $2.11(1)$ & $0.011(2)$ & $6(1)$ & $2.11(2)$ & $0.009(1)$ \\
\hline & $\mathrm{Zr}$ & $6(2)$ & $3.36(1)$ & $0.015(4)$ & $4(1)$ & $3.39(1)$ & $0.010(5)$ \\
\hline \multirow[t]{2}{*}{550} & $\mathrm{O}$ & $4(2)$ & $2.14(1)$ & $0.009(2)$ & $4.3(6)$ & $2.11(1)$ & $0.005(1)$ \\
\hline & $\mathrm{Zr}$ & $4(2)$ & $3.52(1)$ & $0.011(4)$ & $4(1)$ & $3.48(1)$ & $0.011(3)$ \\
\hline
\end{tabular}

Spectra were analysed with UW EXAFS program [4] using FEFF6 code for the ab initio calculation of scattering paths. Fourier transforms of $k^{3}$ weighted spectra in the interval from $4 \AA^{-1}$ to $10 \AA^{-1}$ are shown in Fig. 1 . Complete list of best fit 
parameters are given in Table 1 . The results are characterized by a large correlation between the coordination number and the Debye-Waller factor: thence large estimated errors of these parameters. For samples heated to $800^{\circ} \mathrm{C}$, the perovskite lattice model [5] is adopted on the basis of XRD findings: very good agreement with the measured data is obtained for the six oxygen atoms in the first shell. The contribution of more distant shells is obscured by noise.

In all samples, oxygen atoms are found in the first shell, and zirconium atoms in the second shell of neighbors. Further shells are not resolved and the $\mathrm{Zr}-\mathrm{Pb}$ correlation cannot be established. Even within this close neighborhood, significant differences are found between the two alkoxide precursors in all stages. In both cases, however, final product at $800^{\circ} \mathrm{C}$ shows the same local structure around $\mathrm{Zr}$, corresponding to the perovskite structure identified by XRD.

In the dried samples, the propoxide precursor exhibits a richer neighborhood, both in $\mathrm{O}$ and $\mathrm{Zr}$ atoms. At $400^{\circ} \mathrm{C}$ six oxygens are identified for both precursors, indicating a possible octahedral coordination around $\mathrm{Zr}$ atoms. Number of $\mathrm{Zr}$ neighbours, however, remains significantly higher in the propoxide sample: also the $\mathrm{Zr}$ - $\mathrm{Zr}$ distances are consistently shorter. The results for $550^{\circ} \mathrm{C}$ samples are not in agreement with a presumed pyrochlore phase identified in XRD: the number of the first shell oxygen neighbours is too low. Additionaly, the $\mathrm{Zr}-\mathrm{Zr}$ distance remains close to that in previous heating stages, while in pyrochlore phase $\mathrm{Pb}$ atoms should be the closest metal neighbors, with $\mathrm{Zr}$ neighbors removed further out. Existence of additional, probably amorphous $\mathrm{ZrO}_{2}$ phase is thus indicated.
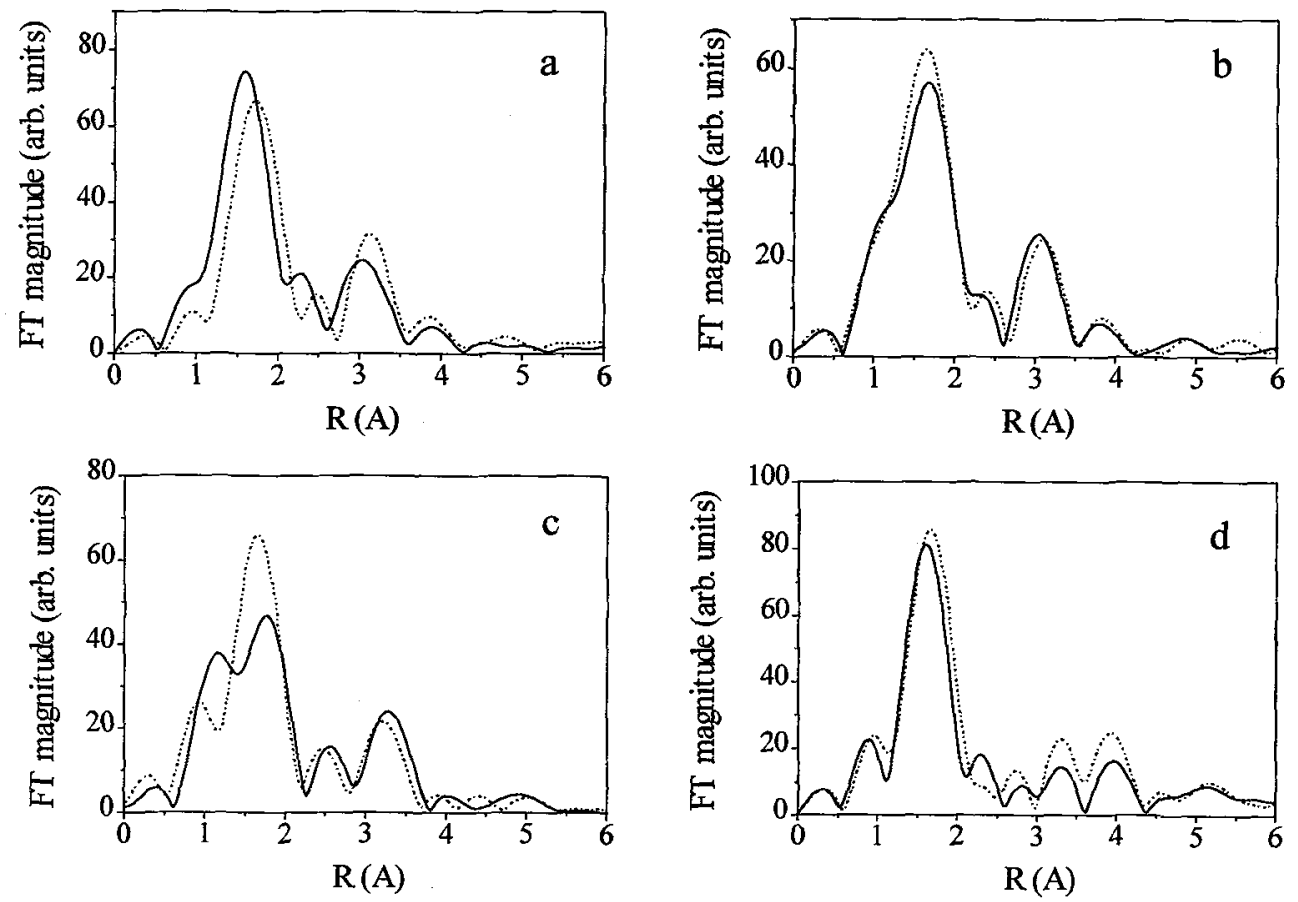

Figure 1. Comparison of Fourier transform magnitudes for propoxide (solid line) and butoxide (dashed line) precursor samples: dried at $150{ }^{\circ} \mathrm{C}$ (a), heated to $400^{\circ} \mathrm{C}$ (b), $550^{\circ} \mathrm{C}$ (c) and $800^{\circ} \mathrm{C}$ (d).

\section{Acknowledgments}

Support of Slovenian Ministry of Science and Technology, the Commission of the European Cormmunities within the Community's Action for Cooperation in Science and Technology with the Central and Eastern European Countries (1992), and Internationales Büro Jülich (Germany) is acknowledged.

\section{References}

1. Kosec M., Malic B., Proc. Electroceramics IV 2, edited by R. Waser, S. Hoffmann (Augustinus Buchhandlung, 1994), $1245-1250$.

2. Chandler C.D., Roger C., Hampden-Smith M. J., Chem. Rev. 93 (1993) 1205-1241.

3. Malix B., Kosec M., Orel B., Silicates Industriels 60 (1995) 163-166.

4. Stern E.A, Newville M., Ravel B., Yacoby Y., Haskel D., Physica B 208\&209 (1995) 117-120.

5. Wyckoff R.W.G., Crystal Structures, Vol. I - VI, (Wiley and Sons, New York 1993) 